\title{
First report of Crumillospongia (Demospongea) from the Cambrian of Europe (Murero biota, Spain)
}

\author{
Diego C. García-Bellido, María Eugenia dies Álvarez, José Antonio GÁmez Vintaned, \\ ELADIO LIÑÁN \& RODOLFO GOZALO
}

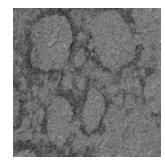

\begin{abstract}
The demosponge genus Crumillospongia, originally described from the Burgess Shale (middle Cambrian of Canada), has only been cited from lower and middle Cambrian localities of North America and China. The taxon is now also described from uppermost lower Cambrian rocks of the Murero Lagerstätte (Zaragoza Province, NE Spain). Crumillospongia mureroensis sp. nov. is a small to medium sized sack-shaped to elongate demosponge characterized by the presence of densely packed pores of three sizes, considerably larger than those in any other species of the genus. The Spanish material represents a link in the chronostratigraphical gap between the Chinese and North American material. - Key words: Crumillospongia, demosponges, early Cambrian, Lagerstätte, taphonomy, Murero, Spain.
\end{abstract}

García-Bellido, D.C., Dies Álvarez, M.E., GÁmez Vintaned, J.A., LiÑán, E. \& GoZAlo, R. 2011. First report of Crumillospongia (Demospongea) from the Cambrian of Europe (Murero biota, Spain). Bulletin of Geosciences 86(3), 641-650 (5 figures, 1 table). Czech Geological Survey, Prague. ISSN 1214-1119. Manuscript received December 30, 2010; accepted in revised form September 5, 2011; published online September 21, 2011; issued September 30, 2011.

Diego C. García-Bellido (corresponding author), Departamento de Geología Sedimentaria y Cambio Ambiental, Instituto de Geociencias (CSIC-UCM), José Antonio Novais 2, 28040 Madrid, Spain; Diego.GBellido@csic.es • María Eugenia Dies Álvarez, Departamento de Didáctica de CC. Experimentales, Facultad de Ciencias Humanas y de la Educación, Universidad de Zaragoza, 22003 Huesca, Spain; medies@unizar.es・José Antonio Gámez Vintaned \& Rodolfo Gozalo, Departamento de Geología, Universitat de València, Dr. Moliner 50, 46100 Burjassot, Spain; gamez@unizar.es,Rodolfo.Gozalo@uv.es•Eladio Liñán, Departamento de Ciencias de la Tierra-IUCA, Universidad de Zaragoza, 50009 Zaragoza, Spain; linan@unizar.es

The Murero Lagerstätte is exposed in the Cadenas Ibéricas, $8 \mathrm{~km}$ from Daroca Village, $80 \mathrm{~km}$ to the southwest of Zaragoza, in the right margin of the Jiloca River. It cuts the Cadena Ibérica Occidental creating a narrow valley located some $700 \mathrm{~m}$ above sea level and parallel to this mountain alignment.

Dry ravines located on the right margin frequently eroded the Tertiary of the Calatayud Basin and allow the study of the subjacent Cambrian materials rich in fossils by means of different outcrops. The better sections in Murero are located at the Rambla de Valdemiedes (Valdemiedes Gully, Fig. 1). A Cambrian monofacial succession $210 \mathrm{~m}$ thick is exposed along the Rambla de Valdemiedes. It is composed of lutites and scarce very fine-grained sandstones of grey, green and red-purple colours, which allow to differentiate three formations. There are some interbedded centimetric to decimetric levels of dolostone and dolomitic nodules. Six sections have been studied previously; from a stratigraphic point of view the most complete are the Rambla de Valdemiedes 1 (RV1) and the Rambla de Valdemiedes 2 (RV2) sections (Liñán \& Gozalo 1986, Liñán et al. 2008), in the west and east banks of the gully, respectively.
Stratigraphically, the Murero site embraces the majority of the Mesones Group (subdivided in ascending order into the Valdemiedes, Mansilla, and Murero formations) and the bottom of the Acón Group (base of the Borobia Formation), with ages ranging from upper Bilbilian (uppermost lower Cambrian) to lower Languedocian (or Cambrian Stage 5 plus Drumian Stage; upper middle Cambrian). The classical "Lower-Middle Cambrian boundary" (approximately coinciding with the limit between Cambrian Series 2 and 3, currently under discussion in the ISCS) is placed at the upper part of the Valdemiedes Formation (Liñán \& Gozalo 1986; Liñán et al. 1992, 2002, 2008). A total of 15 trilobite zones are recognised in the Cambrian strata of Murero, which are useful both for Spanish and Mediterranean Cambrian stratigraphy and biochronology (Liñán et al. 2002, Gozalo et al. 2008).

The palaeontological record in the Murero site is composed of many groups, and each formation yields diverse fossils of exceptional preservation (Murero biota), such as complete trilobite carapaces with minute detail, brachiopods with preserved peduncle, bradoriids with articulated valves, complete articulated echinoderms (cinctans, 


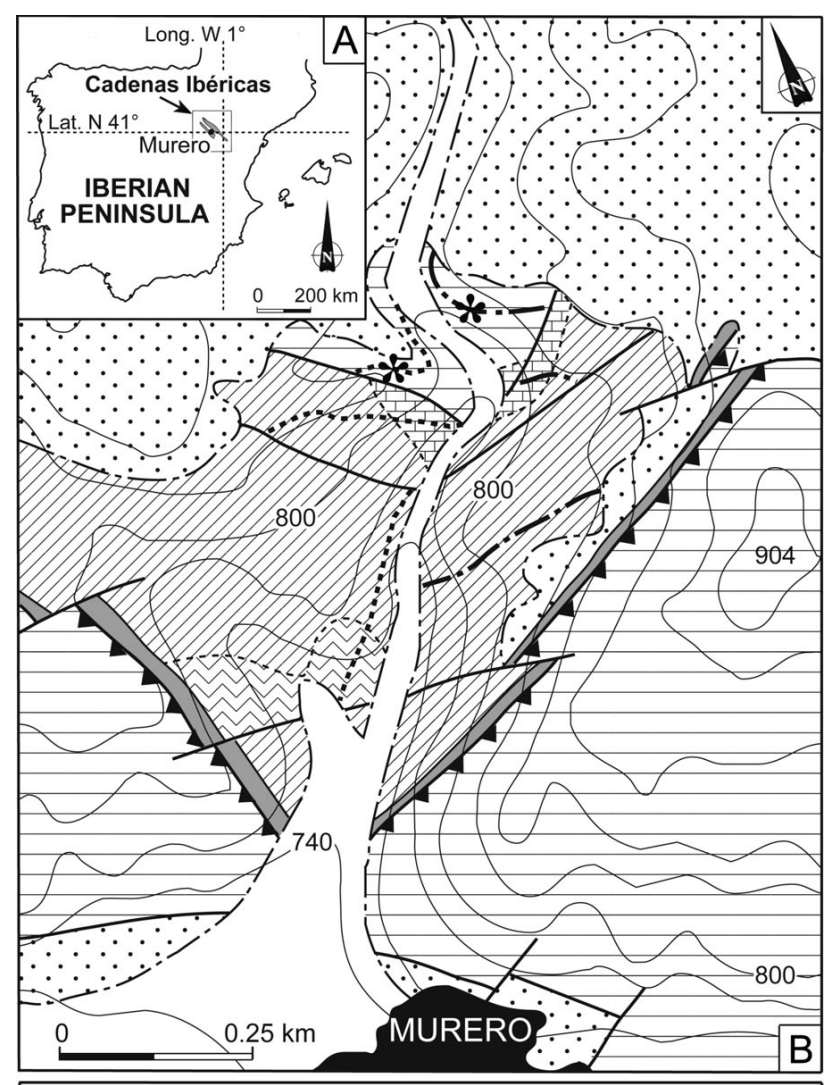

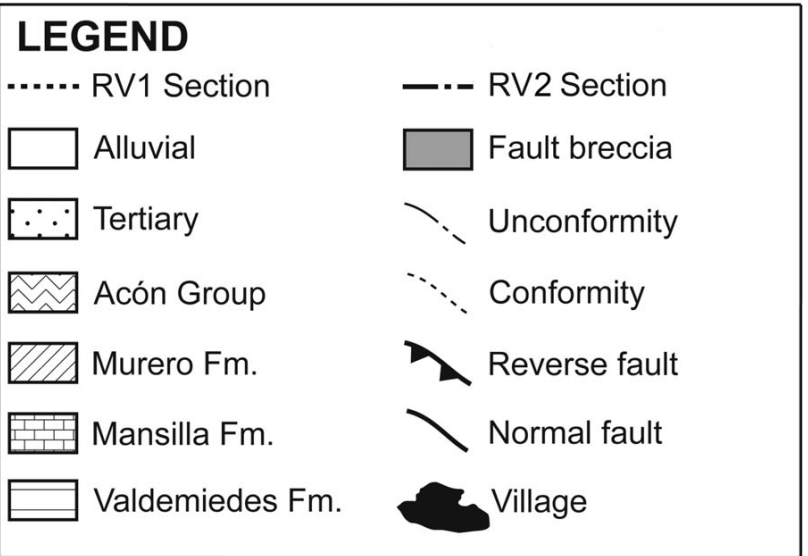

Figure 1. Location map (A) and geological map (B) of the Rambla de Valdemiedes, Murero, Iberian Chains (modified from Gozalo \& Liñán 1988). The levels of RV1 and RV2 sections that produced Crumillospongia mureroensis sp. nov. are marked by an asterisk.

eocrinoids, and edrioasteroids), sponges, palaeoscolecid and eucephalorhynch worms, xenusian lobopods, and ichnofossils, among others (Liñán et al. 2008). The preservation of the Murero biota is due to replication of integuments, skeletons, and some soft tissues in authigenic clay minerals, mainly in the form of chlorite and illite (Zhuravlev et al. 2008).

The objective of this work is to describe a new upper Bilbilian (uppermost lower Cambrian) demosponge recorded in the Valdemiedes Formation from RV1 and RV2 sections in Murero (Fig. 2). This will contribute to a better understanding of the Murero biota during the latest early Cambrian, which represents the only window known to study a complete community (skeletal and soft-bodied fossils) of a shallow environment (infralittoral bioma; sensu Liñán \& Mergl 2001) during this lapse of time in the world (Liñán et al. 2008).

Previously, Crumillospongia has been recorded in Canada, the United States and South China (Chen 2004, Dornbos et al. 2005, Wang et al. 2005, and perhaps Johnston et al. 2009). The discovery of Crumillospongia in Murero extends the palaeobiogeography of the genus to the Acadobaltic province (sensu Sdzuy 1972, Sdzuy et al. 1999), located in the northwestern margin of Gondwana, yet in slightly higher latitude than the other occurrences. A similar palaeobiogeographical distribution has been observed for the middle Cambrian demosponge Leptomitus, also reported in Murero (García-Bellido Capdevila 2003, García-Bellido et al. 2007).

\section{Systematic palaeontology}

Class Demospongea Sollas, 1883

Order Protomonaxonida Finks \& Rigby, 2004

Family Hazeliidae De Laubenfels, 1955

Type genus. - Hazelia Walcott, 1920.

List of included genera. - Lasiocladia Hinde, 1884, Hazelia Walcott, 1920, Falospongia Rigby, 1986 and Crumillospongia Rigby, 1986.

\section{Genus Crumillospongia Rigby, 1986}

Type species. - Crumillospongia frondosa (Walcott, 1919), middle Cambrian, Burgess Shale, Canada.

Other species. - Crumillospongia biporosa Rigby, 1986, also from the Burgess Shale. Various Crumillospongia sp. have been cited and figured from the lower Cambrian Chengjiang biota (Chen et al. 1996, Chen \& Zhou 1997, Chen 2004, Wang et al. 2005). There are putative representatives of the genus from the middle Cambrian Wheeler Formation of Utah mentioned and illustrated in the World Wide Web.

Diagnosis. - "Sack-shaped to globular or globose sponges with thin walls of principally vertical, subparallel, monaxial spicules that form tracts around circular canals of at least two sizes; gastral layer a vertical, monaxial thatch that is less perforate; skeleton with weakly developed tufts; marginalia or prostalia absent" (Finks \& Rigby 2004, p. 28). 

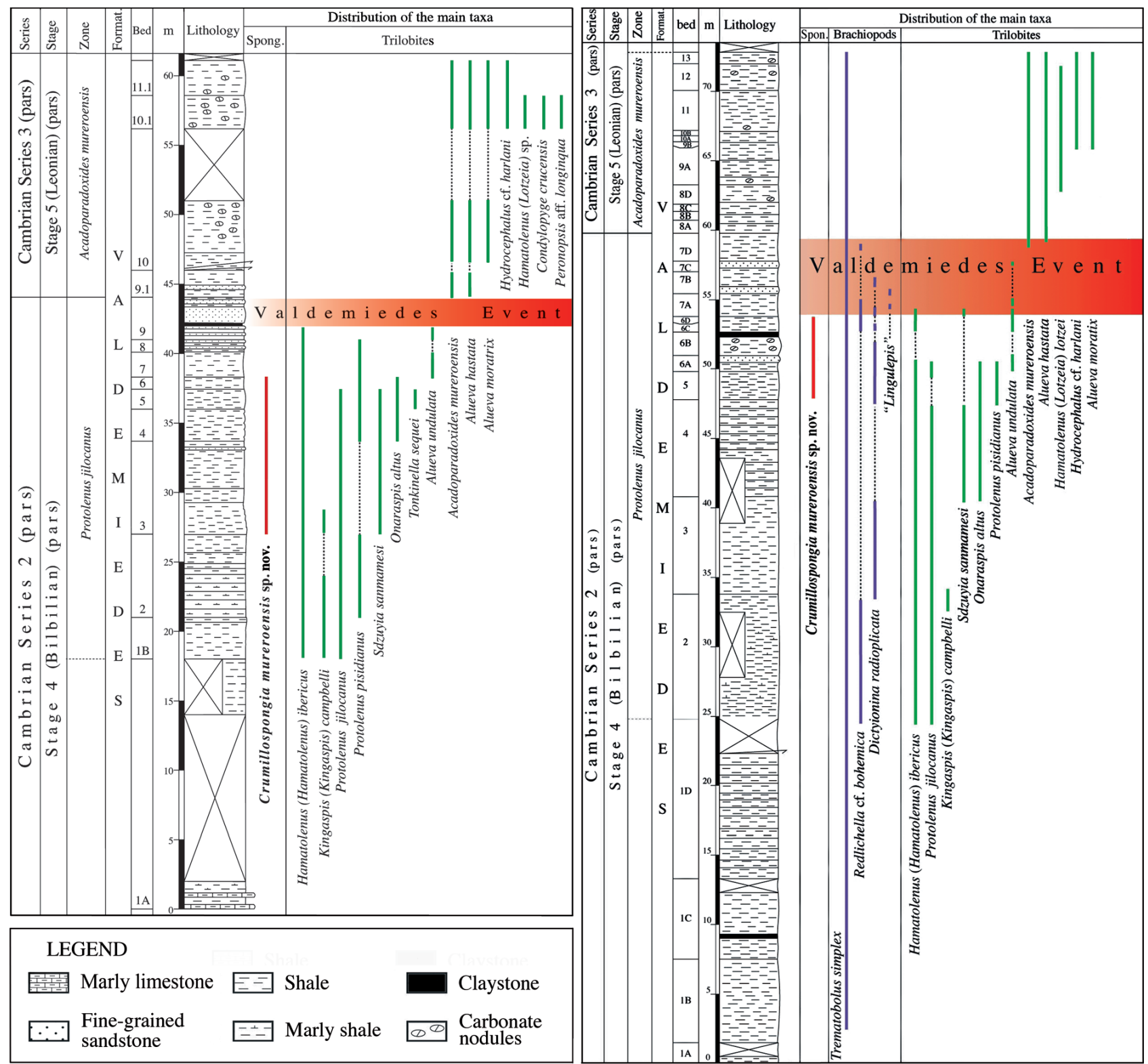

Figure 2. Stratigraphy of the Valdemiedes Formation at the Rambla de Valdemiedes 1 (RV1, left) and 2 (RV2, right) sections, showing the distribution of Crumillospongia mureroensis sp. nov. beside that of the main brachiopod and trilobite taxa (modified from Liñan et al. 1993).

\section{Crumillospongia mureroensis sp. nov.}

Figures 3-5

2008 Crumillospongia biporosa Rigby, 1986. - Liñán et al., fig. $19 \mathrm{c}$.

Types. - All specimens are housed in the collections of the Museo Paleontológico de Zaragoza (MPZ), Spain. Holotype (MPZ 2009/173) and nineteen paratypes (MPZ 2008/158, MPZ 2009/498-MPZ 2009/508, MPZ 2009/510-15, and MPZ 2010/958), most with part and counterpart.
Type horizon and locality. - The levels producing these fossils (RV1/3-6 and RV2/5-6) correspond to the Valdemiedes Formation, Bilbilian Stage, Cambrian Series 2, but the specimens described and figured here were collected in particular from the SE bank of the Rambla de Valdemiedes, in what is known as the RV1 section, some $500 \mathrm{~m}$ north of the town of Murero, Province of Zaragoza (NE Spain).

Material. - Twenty-six specimens (MPZ 2008/158, MPZ 2009/175, MPZ 2009/497-MPZ 2009/518, and MPZ 2010/958), most preserved as chlorite carcasses on a beige 
Table 1. Dimensions in millimetres of Crumillospongia frondosa (Walcott, 1919), Crumillospongia biporosa Rigby, 1986 and Crumillospongia mureroensis sp. nov. Some values presented as ranges, with exceptional maximum values in parentheses. $\mathrm{L}=$ length, $\varnothing=$ diameter.

\begin{tabular}{|c|c|c|c|c|c|c|}
\hline & Length & Width & Large pore $\varnothing$ & Medium pore $\varnothing$ & Small pore $\varnothing$ & L pore spacing \\
\hline C. frondosa (Walcott, 1919) & $10-55(150)$ & $13-80(130)$ & $2,2.5 \times 3(3.5)$ & $0.7-1.2$ & (0.2) $0.3-0.5$ & $3-5$ \\
\hline C. biporosa Rigby, 1986 & $19-20$ & $14-16$ & $0.5-0.8$ & - & $0.2-0.3$ & 0.7 \\
\hline \multicolumn{7}{|l|}{ C. mureroensis sp. nov. } \\
\hline MPZ 2008/158a, b & 32 & 17 & $1.2 \times 2.8-1.5 \times 3.5$ & $0.8 \times 1.5-1.2 \times 2$ & $0.2-0.5,0.5 \times 1-0.6 \times 1.2$ & $2.5-3.5$ \\
\hline MPZ 2009/173a, b & 28 & 18 & $(1 \times 1.5) 1 \times 2-1.5 \times 3$ & $1 \times 1.5-1 \times 2$ & $0.1-0.5,0.5 \times 1$ & $1.8-2$ \\
\hline MPZ 2009/498 & 40 & 11 & $1 \times 2-1.5 \times 2.5$ & $0.6 \times 1.5$ & $0.3-0.5,0.4 \times 0.8$ & 2 \\
\hline MPZ 2009/499 & 35 & 15 & $1 \times 1.8-1 \times 2.2$ & $0.5 \times 1.1$ & $0.2 \times 0.4,0.3-0.5$ & $2-3$ \\
\hline MPZ 2009/500a, b & 65 & 21 & $1.2 \times 3-1.5 \times 3.7$ & $0.8 \times 1.5$ & $0.1-0.5,0.5 \times 0.8-0.6 \times 1.2$ & $1.5-3$ \\
\hline MPZ 2009/501 & 20 & 10 & $1.2 \times 2.2-1.7 \times 2.7$ & $0.7 \times 1.4$ & $0.4-0.6$ & $0.7-1.2$ \\
\hline MPZ 2009/502 & 15 & 11 & $0.7 \times 1.6-1 \times 1.5$ & $0.5 \times 0.7-0.7 \times 1$ & $0.2-0.4$ & $0.5-1.5$ \\
\hline MPZ 2009/503 & 93 & 25 & $1.5 \times 3.5-2 \times 5$ & $0.9 \times 1.5-1.2 \times 3$ & $0.1-0.5,0.5 \times 1-0.7 \times 1.2$ & $2-4(5)$ \\
\hline MPZ 2009/504a, b & 20 & 15 & $2 \times 3$ & $1.1 \times 2.6$ & $0.1-0.7$ & $1-3$ \\
\hline MPZ 2009/505a, b & 21 & 11 & $1 \times 1.7-1 \times 2$ & $0.5 \times 1.5,0.6$ & $0.1-0.4$ & $2-2.5$ \\
\hline MPZ 2009/506 & 18 & 16 & $0.7 \times 1.7-1 \times 2.5$ & $0.5 \times 0.8-0.7 \times 1.4$ & $0.15 \times 0.22-0.28 \times 0.48$ & $0.9-2.5$ \\
\hline MPZ 2009/507 & 23 & 12 & $1.2 \times 1.5-1.2 \times 2.5$ & $0.5 \times 1.1-0.7 \times 1.2$ & $0.3-0.5$ & $1.5-2.5$ \\
\hline MPZ 2009/508a, b & 25 & 15 & $2 \times 3-2.5 \times 3$ & $0.6 \times 1.5-0.8 \times 2$ & $0.1-0.5,0.5 \times 1$ & $0.5-1$ \\
\hline MPZ 2009/510a, b & 27 & 18 & $1.5 \times 2.5-2 \times 3$ & $0.7 \times 1.4$ & $0.2-0.8$ & $0.5-1$ \\
\hline MPZ 2009/511 & 35 & 10 & $0.6 \times 1.2-0.7 \times 1.5$ & $0.15 \times 0.6-0.25 \times 0.75$ & $0.2-0.5$ & $1-1.5$ \\
\hline MPZ 2009/512a, b & 40 & 30 & $1 \times 2$ & $1 \times 1.5$ & $0.4-0.5$ & $1-1.5$ \\
\hline MPZ 2009/513a, b & 35 & 20 & $1.5 \times 3-2 \times 3.5$ & $1.2 \times 2.2$ & - & $1.5-2$ \\
\hline MPZ 2009/514 & 23 & 16 & $1.45 \times 1.8$ & $0.85 \times 1.45$ & 0.45 & $1.45-2.15$ \\
\hline MPZ 2009/515 & 54 & 13 & - & - & - & - \\
\hline \multicolumn{7}{|l|}{ C. cf. C. mureroensis sp. nov. } \\
\hline MPZ 2009/497a, b & 80 & 70 & $1.5 \times 3-2.5 \times 4$ & $0.8 \times 1.5-1 \times 1.8$ & $0.1-0.5$ & $2-3$ \\
\hline MPZ 2009/509 & 75 & 42 & $2 \times 3-2 \times 4.3$ & $0.5 \times 1.2-1.5 \times 2.5$ & $0.1-0.5,0.6 \times 0.7-0.7 \times 0.8$ & $2-3.5$ \\
\hline
\end{tabular}

lutitic matrix and a few partially or totally replaced by limonite, with excellent transitional examples. Two other specimens are assigned to the species with doubts, and about a dozen smaller fragments have also been collected, but are not well enough preserved or complete to warrant their measurement.

Etymology. - After the name of the village closest to the outcrop.

Diagnosis. - Small to medium-sized sack-shaped to elongate sponges, with thin walls densely perforated by circular to elliptical pores of three sizes, the largest of which show a largest dimension from 1.2 to $3.7 \mathrm{~mm}$. Large apical oscu- lum. Evidence of gastral layer, tufts, marginalia or prostalia lacking.

Description. - All specimens have suffered compaction and are preserved as two dimensional bodies, but these sponges would have been oval to elongated in life (Figs 3A, B, 4C, 5A). The best preserved specimen (Fig. 3A, B) is $28 \mathrm{~mm}$ high and $38 \mathrm{~mm}$ wide, with partial specimens ranging from 15 by $10 \mathrm{~mm}$ to 65 by $20 \mathrm{~mm}$, and the largest fragments reaching up to 93 by $25 \mathrm{~mm}$. Extrapolation from the largest fragments (Figs 3D, 4A, B), would produce specimens with a maximum of $100 \mathrm{~mm}$ high by $c a$ $70 \mathrm{~mm}$ wide. The outline and detail of these sponges comes from their preserved organic framework, since spicules can

Figure 3. Crumillospongia mureroensis sp. nov., from the late early Cambrian Valdemiedes Formation, Murero, Iberian Chains, Spain. • A, B - holotype, almost complete specimen showing the globose shape of the sponge with a lateral outgrowth (possibly a root tuft), immersed in water, part (A) and counterpart (B), MPZ 2009/173a, b (RV1/4C/1a, b). • C - paratype, partial specimen, dry, MPZ 2009/500b (RV1/4C/5”b). • D - paratype, largest specimen in the collection, incomplete on the right side due to break in the rock, dry, MPZ 2009/503a (RV1/4R/203a). • E - paratype, partial specimen preserving the osculum (arrow), dry, MPZ 2008/158b (RV1/4R/208b). All specimens are from Rambla de Valdemiedes Section 1, and are housed in the collections of the Museo Paleontológico de Zaragoza. Scale bars: $5 \mathrm{~mm}$. 

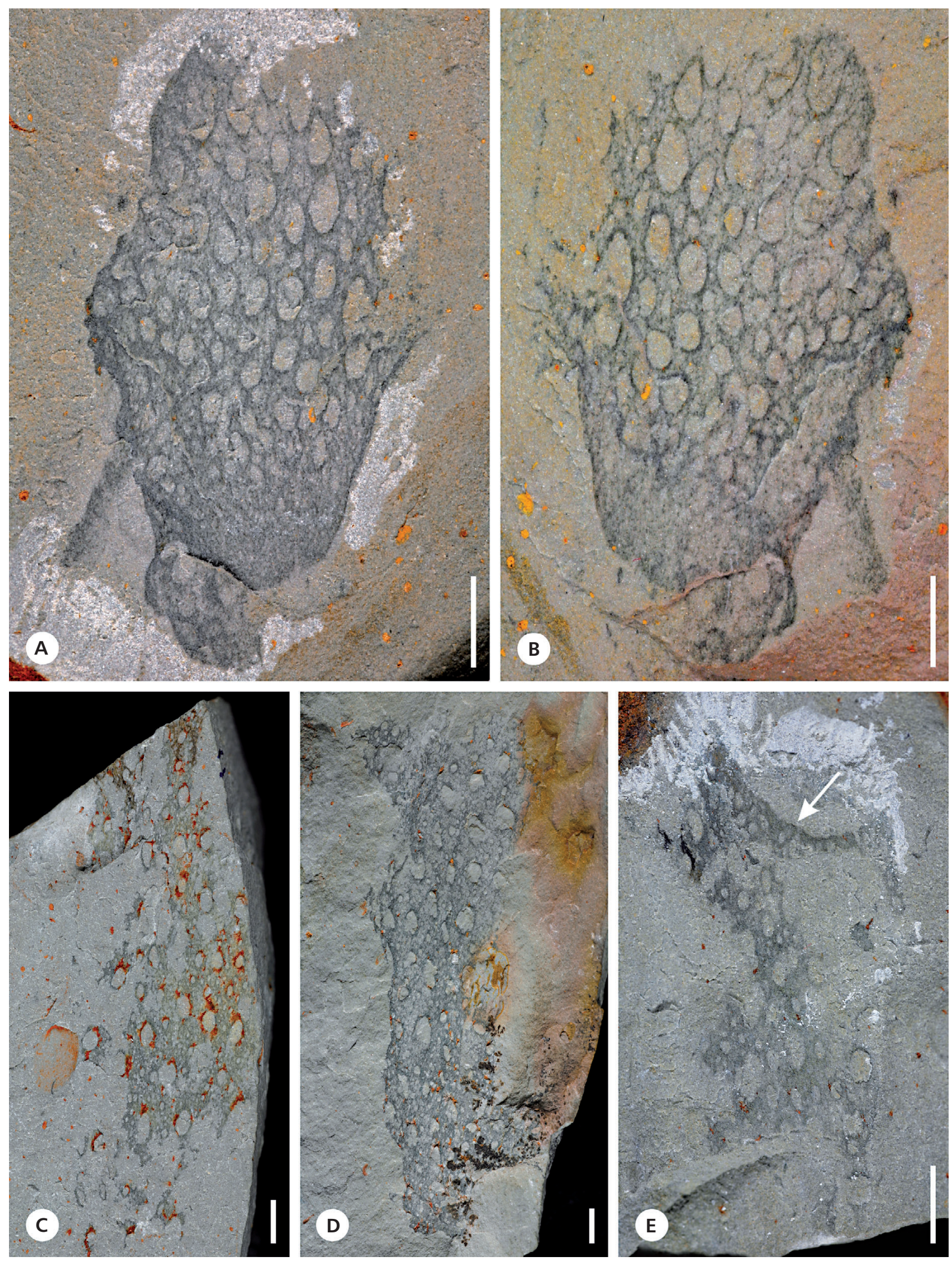
no longer be recognized. Circular to elliptical pores densely perforate the thin dermal wall. Although pores are generally smaller at the base than at the top of the sponge (Fig. 3A, B), there are tree distinct pore sizes in all the specimens. Largest pores are generally 2 by $5 \mathrm{~mm}$, intermediate pores are 1 by $2 \mathrm{~mm}$ and small pores are 0.1 to $0.5 \mathrm{~mm}$ in diameter. Spacing between large pores ranges between 1 and $4 \mathrm{~mm}$, while spacing between medium pores is 0.85 to $1.15 \mathrm{~mm}$. The most complete specimen shows general increase in large pore size towards the top of the sponge. This specimen also shows a lateral outgrowth $(7 \mathrm{~mm}$ long and $2 \mathrm{~mm}$ wide), which probably corresponds to a root tuft and could have been used to stabilize the sponge on the sea floor. Nevertheless, no such structure has been described until now in Crumillospongia, and, although apparently continuous with the sponge body, it may correspond to chance superposition. One of the specimens (Fig. 3E) seems to preserve the oscular margin. The oscular diameter appears to be more than half of that of the sponge. Two specimens (MPZ 2009/497 and MPZ 2009/509) are considerably wider than the other fragments, and despite having pore-sizes within the range of the new species, they have been assigned to it with doubt (Table 1).

Discussion. - The new Crumillospongia species is more elongated than the globular C. biporosa and C. frondosa (Rigby \& Collins 2004). It is intermediate in size between the former and the latter, but considerably larger than other Crumillospongia specimens, such as those in the lower Cambrian Chengjiang biota (e.g. Wang et al. 2005) and the middle Cambrian Chancellor Basin, Canada (Johnston et al. 2009). The Spanish species has three pore sizes, like C. frondosa, but they are more densely packed, with spacing between its large pores generally of 0.5 to $3 \mathrm{~mm}$. However, the pores in the new species are consistently larger than those in any of the other species described to date. Unfortunately, the preservation of the Spanish material does not allow comparison at a spicular level, since no spicules have been recognized. Regarding age, C. mureroensis sp. nov. is intermediate between the Chinese and the North American specimens.

\section{Taphonomy}

The new Crumillospongia specimens show an interesting gradation in preservation showing advancing decay stages. Better-preserved specimens (Figs 3, 4) are more or less complete bodies, where the spicular skeleton has been lost and only the underlying collagenous framework (probably spongin) is preserved, basically in the form of chlorite (Figs 3C-E, 4D, E). However, a few specimens (best represented by Fig. 5A-C) show varying degrees of decomposition of the proteinaceous structure to the stage where they are only recognizable by the somewhat polygonal shape of the decayed pore edges, surrounded by limonite. This limonite would almost surely have been pyrite in origin, formed as the sponge's organic material decomposed and its spicules disolved, precipitating pyrite, which was later fossildiagenetically transformed to the hydrated iron oxyde.

\section{Biochronology and correlation}

The Cambrian was a geological period characterized by important faunal provinciality. This phenomenon is the first time recorded in the Earth history during the Cambrian. This provinciality makes difficult to establish a common biochronological scale; thus, it has been used a different regional stage nomenclatures are commonly employed with the exception of some of them which has been already replaced by the International Subcommission on Cambrian Stratigraphy by official and global names in the last few years (see Babcock \& Peng 2007, Babcock et al. 2007, Landing et al. 2007, Peng et al. 2009).

The Spanish regional stages are named Corduban, Ovetian, Marianian and Bilbilian for the lower Cambrian, as well as Leonian, Caesaraugustan and Languedocian for the middle Cambrian; they are frequently used for the Mediterranean region (see Sdzuy et al. 1999, Liñán et al. 2002).

The Valdemiedes Formation (lower Bilbilian-middle Leonian) contains the classic Lower-Middle Cambrian boundary recorded at the first appearance datum (FAD) of the trilobites Acadoparadoxides mureroensis (Fig. 2). This FAD limits the Valdemiedes Extinction Event (VEE), which is concurrent with the disappearance of all but one genera of Protoleninae, Ellipsocephalinae, and Resseropinae trilobites in the Cadenas Ibéricas. Extinct trilobite taxa were replaced by new assemblages at the base of the Cambrian Series 3, including paradoxidids (Liñán et al. 1993, 2008; Sdzuy et al. 1999; Dies et al. 2004; Gozalo et al. 2007; Liñán et al. 2010).

Crumillospongia mureroensis sp. nov. is recorded in levels 3 to 6 of the RV1 section and also some small fragments in levels 5 and 6 of the RV2. The new poriferan species is associated with trilobites (Kingaspis campbelli, Parasolenopleura sp., Hamatolenus (Hamatolenus) ibericus, Protolenus jilocanus, $P$. pisidianus, Onaraspis altus, Tonkinella sequei, Sdzuyia sanmamesi and Condyolopyge sp.; see Gozalo et al. 2008) of the Protolenus jilocanus Zone [former Hamatolenus (H.) ibericus Zone, uppermost Bilbilian; (Fig. 2)]; brachiopods (Trematobolus simplex, "Lingulella" sp. and Redlichiella cf. bohemica; see Liñán \& Mergl 2001); algae, edrioasteroids, hyoliths, palaeoscolecids worms, xenusian lobopods and several non-trilobitic arthropods are also present in the association (see Liñán et al. 2008).

The Crumillospongia levels could be correlated by means of their trilobite record with the Australian Ordian 

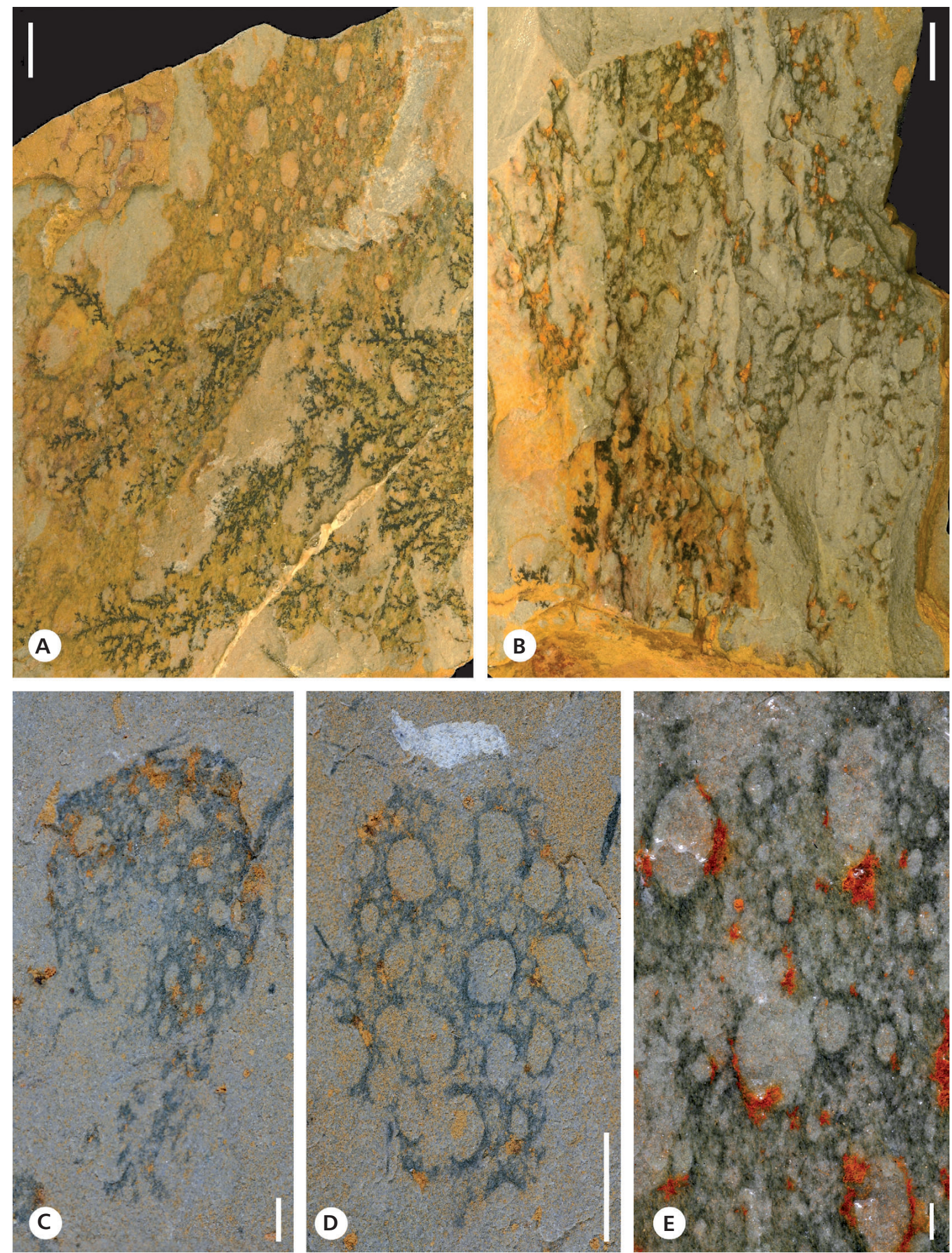

Figure 4. Crumillospongia cf. C. mureroensis sp. nov. (A, B) and Crumillospongia mureroensis sp. nov. (C-E) from the late early Cambrian Valdemiedes Formation, Murero, Iberian Chains, Spain. • A - large specimen, with overlying pyrolusite dendrites, immersed in water, MPZ 2009/497a (RV1/4C/2a). • B - large specimen, immersed in water, MPZ 2009/509 (RV1/5R/1). • C - paratype, almost complete small specimen, dry, MPZ 2009/505b (RV1/4R/204 IIb). D - paratype, small fragment, dry, MPZ 2009/504b (RV1/4R/204 Ib). E - paratype, detail of specimen in Fig. 3C showing large, medium and small pores, some pyritic rust can be recognized in the edges of larger pores, immersed in water, MPZ 2009/500b (RV1/4C/5"b). All specimens are from Rambla de Valdemiedes Section 1, and are housed in the collections of the Museo Paleontológico de Zaragoza. Scale bars $5 \mathrm{~mm}$, except E: $1 \mathrm{~mm}$. 

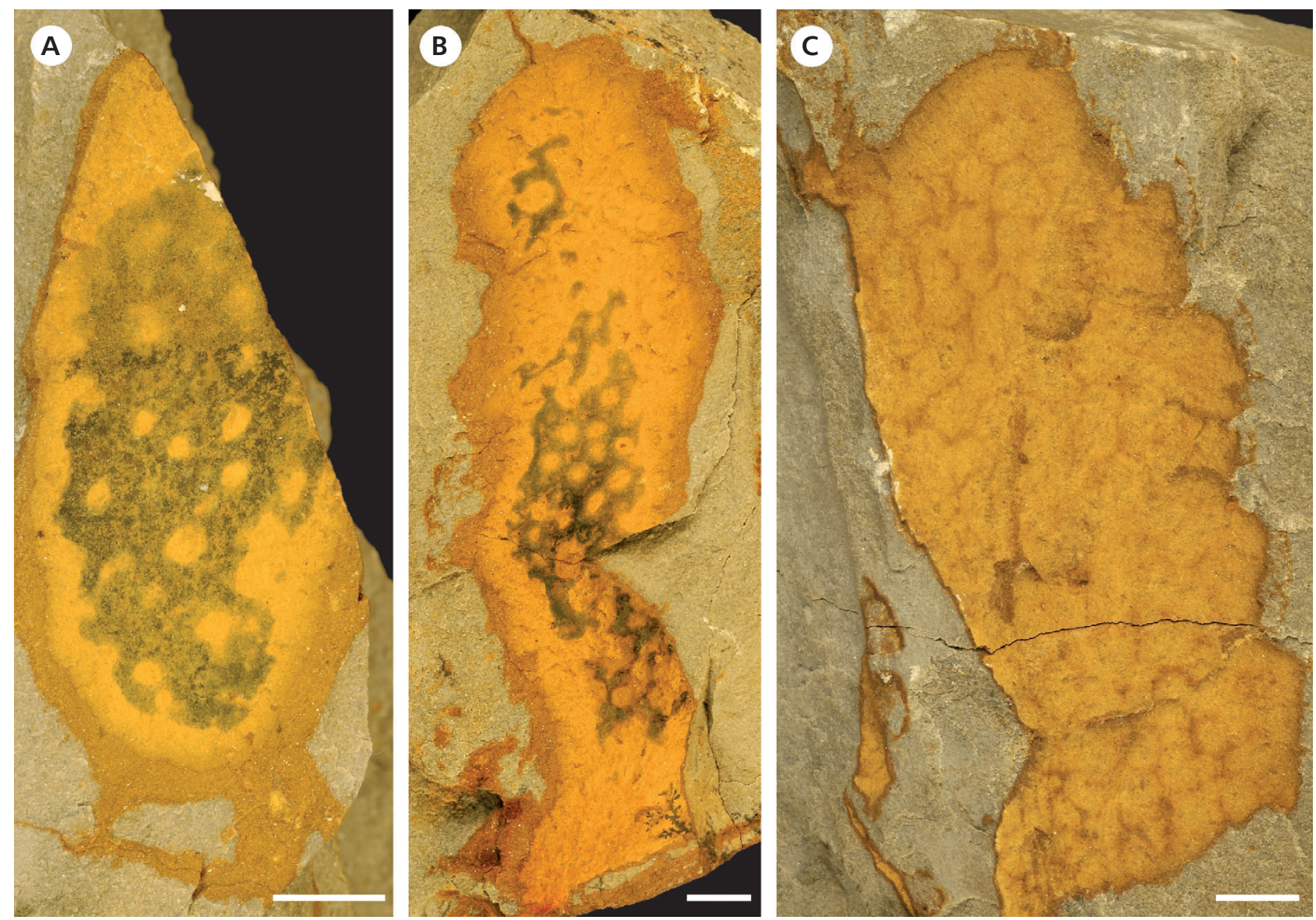

Figure 5. Crumillospongia mureroensis sp. nov., from the late early Cambrian Valdemiedes Formation, Murero, Iberian Chains, Spain. • A - paratype, slightly decayed specimen, where outline of the wall with large, medium and some small pores can still be recognized, dry, MPZ 2009/514 (RV1/4F/7). • B - paratype, considerably decayed specimen, where outline is lost and almost only large pores are recognizable, dry, MPZ 2009/515 $(\mathrm{RV} 1 / 4 \mathrm{R} / 301) \cdot \bullet \mathrm{C}$ - paratype, almost completely decayed specimen, where only a polygonal pattern remains from the pores in the sponge wall, dry, MPZ 2010/958 (RV1/4-5). All specimens are from Rambla de Valdemiedes Section 1, and are housed in the collections of the Museo Paleontológico de Zaragoza. Scale bars: $5 \mathrm{~mm}$.

Stage (see Dies Álvarez et al. 2007) and the presence of Kingaspis campbelli allows a good correlation with the Cambrian of Jordan and Israel (see Liñán et al. 2003). Also, the presence of several species of Protolenus permits the correlation with Avalonia and Morocco (see Gozalo et al. 2007). Furthermore, the FAD of Acadoparadoxides mureroensis occurs only $5 \mathrm{~m}$ above the last record of the Crumillospongia studied herein; this FAD has been roughly correlated with the Ovatoryctocara granulata FAD or slightly below of the Oryctocephalus indicus FAD, both are considered as candidates marking the base of Cambrian Stage 5 and Cambrian Series 3 (see Gozalo et al. 2007). Then the age of the new demosponge species in Murero is uppermost Cambrian Stage 4 and Series 2 in the new proposal of the ISCS, i.e. uppermost lower Cambrian in the classical sense.

Crumillospongia mureroensis disappears immediately below the Valdemiedes Event and has not been found in middle Cambrian strata. Later on, during
Caesaraugustan times (equivalent to the top of Stage 5 of the Cambrian and part of the Drumian Stage in the new proposals of the ISCS), the demosponge Leptomitus is found playing a similar role in the benthic communities of Murero (García-Bellido Capdevila 2003, García-Bellido et al. 2007).

\section{Conclusions}

The new demosponge species Crumillospongia mureroensis is defined from uppermost lower Cambrian rocks in Murero (Cadenas Ibéricas). This is the first reference to the genus in both the Acadobaltic province and Europe. The new species appears at the Protolenus jilocanus Zone (uppermost lower Cambrian) and disappears right before the beginning of the Valdemiedes Extinction Event (VEE), which marks the lower/middle Cambrian boundary in the Mediterranean region. 


\section{Acknowledgements}

We thank valuable comments from Joseph Botting, Radek Vodrážka, and the editor of this volume. This publication is a contribution to Secretaría de Estado de Universidades e Investigación Projects Consolíder CGL2006-12975/BTE, CGL2009-07073 and CGL2011-24516, the 'Ramón y Cajal' and 'Juan de la Cierva' Programmes (references RYC-2007-00090 and JCI-2009-05319) of the Spanish Ministerio de Ciencia e Innovación, and Group E17 of the Departamento de Ciencia, Tecnología y Universidad del Gobierno de Aragón. We sincerely acknowledge field assistance by Samuel Zamora, Jorge Esteve (both from Universidad de Zaragoza), and fellows from APA and SAMPUZ. I. Pérez Urresti (MEC-European Social FundUniversidad de Zaragoza) assisted with some of the drafting and photographs, and we are grateful for her contribution.

\section{References}

BABCOCK, L.E. \& Peng, S.C. 2007. Cambrian chronostratigraphy: Current state and future plans. Palaeogeography, Palaeoclimatology, Palaeoecology 254, 62-66.

DOI 10.1016/j.palaeo.2007.03.011

Babcock, L.E., Robison, R.A., Rees, M.N., Peng, S.C. \& SAltzMAn, M.R. 2007. The Global boundary Stratotype Section and Point (GSSP) of the Drumian stage (Cambrian) in the Drum Mountains, Utah, USA. Episodes 30, 84-94.

CHEN, J.Y. 2004. The Dawn of Animal World. 366 pp. Jiangsu Science and Technology Press, Nanjing. [in Chinese]

Chen, J.Y. \& Zhou, G.C. 1997. Biology of the Chengjiang fauna, 11-103. In Chen, J.Y, Cheng, Y.N. \& Van Iten, H. (eds) The Cambrian explosion and the fossil record. Bulletin of National Museum of Natural Science 10.320 pp. Taichung, Taiwan.

Chen, J.Y., Zhou, G.C., Zhu, M.Y. \& Yен, K.Y. 1996. The Chengjiang biota - A unique window of the Cambrian explosion. 222 pp. National Museum of Natural Science, Taichung, Taiwan.

De Laubenfels, M.W. 1955. Porifera, E21-E121. In Moore, R.C. (ed.) Treatise on Invertebrate Paleontology. Part E. Archeaocyatha and Porifera. Geological Society of America \& University of Kansas Press, Boulder \& Lawrence.

Dies, M.E., Gozalo, R. \& Liñán, E. 2004. Zonación del Límite Bilbiliense-Leoniense (Formación Valdemiedes, Cámbrico Inferior-Medio) en las Cadenas Ibéricas. Geo Temas 6(2), 283-286.

Dies Álvarez, M.E., Liñán, E. \& Gozalo, R. 2007. The Cambrian genus Onaraspis Öpik, 1968 (Trilobita), in Spain. Memoirs of the Association of Australasian Palaeontologists 34, 419-429.

Dornbos, S.Q., Bottuer, D.J. \& Chen, J.Y. 2005. Paleoecology of benthic metazoans in the Early Cambrian Maotianshan Shale biota and the Middle Cambrian Burgess Shale biota: evidence for the Cambrian substrate revolution. Palaeogeography, Palaeoclimatology, Palaeoecology 220, 47-67.

DOI 10.1016/j.palaeo.2003.11.01

Finks, R.M. \& RigbY, J.K. 2004. Paleozoic Demosponges, 9-175. In KAESLER, R.C. (ed.) Treatise on Invertebrate Paleontology. Part E, Vol. 3 (revised). Porifera (Demospongea, Hexa- ctinellida, Heteractinida, Calcarea). 902 pp. Geological Society of America, Kansas.

García-Bellido Capdevila, D. 2003. The Demosponge Leptomitus $\mathrm{cf}$. L. lineatus, first occurrence from the Middle Cambrian of Spain (Murero Formation, Iberian Chains). Geologica Acta 1, 113-119.

García-Bellido, D.C., Gozalo, R., Chirivella Martorell, J.B. \& LIÑÁn, E. 2007. The Demosponge genus Leptomitus and a new species from the Middle Cambrian of Spain. Palaeontology 50, 467-478.

GozAlo, R. \& LiÑÁn, E. 1988. Los materiales hercínicos de la Cordillera Ibérica en el contexto del Macizo Ibérico. Estudios geológicos 44, 399-404.

Gozalo, R., Lińán, E., Dies, M.E., Gámez Vintaned, J.A. \& MAYORAL, E. 2007. The Lower-Middle Cambrian boundary in the Mediterranean subprovince, 359-373. In Linnemann, U., Nance, R.D., Kraft, P. \& Zulauf, G. (eds) The evolution of the Rheic Ocean: From Avalonian-Cadomian active margin to Alleghenian-Variscan collision. Geological Society of America Special Paper 423.

Gozalo, R., Liñán, E., Gámez Vintaned, J.A., Dies Álvarez, M.E., Chirivella Martorell, J.B., Zamora, S., Esteve, J. \& Mayoral, E. 2008. The Cambrian of the Cadenas Ibéricas (NE Spain) and its trilobites. Cuadernos del Museo Geominero 9, 137-151.

HindE, G.J. 1884. Catalogue of the fossil sponges in the Geological Department of the British Museum (Natural History). viii + 248 pp. British Museum (Natural History), London.

Johnston, K.J., Johnston, P.A. \& Powell, W.G. 2009. A new Middle Cambrian Burgess Shale-type biota, Bolaspidella Zone, Chancellor Basin, southeastern British Columbia. Palaeogeography, Palaeoclimatology, Palaeoecology 277, 106-126. DOI 10.1016/j.palaeo.2009.02.015

Landing, E., Peng, S., Babcock, L.E., Geyer, G. \& MoczydlowSKA-VIDAL, M. 2007. Global standard names for the Lowermost Cambrian Series and Stage. Episodes 30, 287-289.

Liñán, E., Dies Álvarez, M.E., Gámez Vintaned, J.A., Gozalo, R., Zhuravlev, A.Y., Subías, I. \& Bauluz, B. 2010. The Valdemiedes Extinction Event (VEE): Biotic crisis and recovery at the Lower/Middle Cambrian boundary, 141-142. In Lamolda, M.A., Díaz, E., Jiménez Moreno, G., Maurrasse, F.J.-M.R., MELÉndez, G., PAul, C.R.C. \& RodRÍGuez TovaR, F.J. (eds) International Conference on Geoevents, Geological Heritage, and the Role of the IGCP. Caravaca de la Cruz. $15^{\text {th }}-18^{\text {th }}$ September, 2010. Abstract Book. Ayuntamiento de Caravaca de la Cruz, Caravaca de la Cruz.

Liñán, E., Dies, M.E. \& Gozalo, R. 2003. A review of the genus Kingaspis (Trilobita, Lower Cambrian) from Spain and its biostratigraphical consequences for correlation in the mediterranean subprovince. Revista Española de Paleontología 18, 3-14.

Liñán, E., Fernández-Nieto, C., Gámez, J.A., Gozalo, R., Mayoral, E., Moreno-Eiris, E., Palacios, T. \& Perejón, A. 1993. Problemática del límite Cámbrico Inferior-Medio en Murero (Cadenas Ibéricas, España). Revista Española de Paleontología, No. extraordinario, 26-39.

Liñán, E. \& Gozalo, R. 1986. Trilobites del Cámbrico Inferior y Medio de Murero (Cordillera Ibérica). Memorias del Museo Paleontológico de la Universidad de Zaragoza 2, 1-104. 
Liñán, E., Gozalo, R., Dies Álvarez, M.E., Gámez Vintaned, J.A., Mayoral, E., Chirivella Martorell, J.B., Esteve, J., Zamora, S., Zhuravlev, A.Y. \& Andrés, J.A. 2008. Fourth International Trilobite Conference Trilo 08 Toledo, Spain, 2008. Post-Conference Field Trip. Lower and Middle Cambrian trilobites of selected localities in Cadenas Ibéricas (NE Spain). 52 pp. Universidad de Zaragoza, Zaragoza.

Liñán, E., Gozalo, R., Gámez, J.A. \& Álvaro, J.J. 1992. Las formaciones del Grupo Mesones (Cámbrico Inferior-Medio) en las Cadenas Ibéricas. III Congreso Geológico de España y VIII Congreso Latinoamericano de Geología, Salamanca, Actas 1, 517-523.

Liñán, E., Gozalo, R., Palacios, T., Gámez Vintaned, J.A., Ugidos, J.M. \& MAYORAL, E. 2002. Cambrian, 17-29. In GiBBons, W. \& Moreno, T. (eds) The Geology of Spain. 350 pp. The Geological Society, London.

Liñán, E. \& Mergl, M. 2001. Lower and Middle Cambrian brachiopods from the Iberian Chains and Sierra Morena (Spain). Revista Española de Paleontología 16, 317-337.

Peng, S.C., BabCock, L.E., Zuo, J., Lin, H., Zhu, X.Y., YAng, X., Robison, R.A., Qi, Y., Bagnoli, G. \& Chen, Y. 2009. The Global Boundary Stratotype Section and Point (GSSP) of the Guzhangian Stage (Cambrian) in the Wuling Mountains, Northwestern Hunan, China. Episodes 32, 41-55.

Rigby, J.K. 1986. The sponges of the Burgess Shale, Middle Cambrian (British Columbia). Palaeontographica Canadiana $2,1-105$.

Rigby, J.K. \& Collins, D.H. 2004. Sponges of the Middle Cam- brian Burgess Shale and Stephen Formations, British Columbia. ROM Contributions in Science 1, 1-155.

SDZuY, K. 1972. Das Kambrium der acadobaltischen Faunenprovinz. Zentralblatt für Geologie und Paläontologie, Teil II, 1972(1/2), 1-91.

SdZuy, K., Liñán, E. \& GoZalo, R. 1999. The Leonian Stage (early Middle Cambrian): a unit for Cambrian correlation in the Mediterranean subprovince. Geological Magazine 136, 39-48.

Sollas, W.J. 1885. A classification of the sponges. Annals of Natural History (series 5) 16, 395.

WalcotT, C.D. 1919. Cambrian Geology and Paleontology IV. No. 5. Middle Cambrian Algae. Smithsonian Miscellaneous Collections 67, 218-260.

WaLcotT, C.D. 1920. Cambrian Geology and Paleontology IV. No. 6. Middle Cambrian Spongiae. Smithsonian Miscellaneous Collections 67, 261-365.

Wang, P.L., Zhao, Y.L., YAnG, X.L. \& Yang, R.J. 2005. Crumillospongia biporosa (Sponge) from the early Cambrian Niutitang Biota in Guizhou Province. Acta Micropalaeontologica Sinica 22, 196-201.

Zhuravlev, A.Y., BauluZ, B., GÁmeZ Vintaned, J.A., LiÑán, E., Gozalo, R., Zamora, S. \& Esteve, J. 2008. A new pane for the Cambrian taphonomic window: Preservation of fossils in the Mesones Group, Cadenas Ibéricas, Spain, 229-230. In Ruiz-Omeñaca, J.I., Piñuela, L. \& García-Ramos, J.C. (eds) Libro de Resúmenes. XXIV Jornadas de la Sociedad Española de Paleontología. Museo del Jurásico de Asturias (MUJA), Colunga, 15-18 de octubre de 2008. 